\title{
Respon Ikan Kembung Terhadap Warna Umpan Pada Alat Tangkap Pancing Ulur Di Teluk Tomini
}

(The Response of Mackerel To The Color Of Bait Hand Line Fishery On The Tomini Bay)

\author{
Asruddin ',Ni'mawati Syariah, Muhammad Hasan* \\ ${ }^{1 *}$ Program Studi Akuakultur, Fakultas Ilmu-Ilmu Pertanian \\ Universitas Muhammadiyah Gorontalo \\ E-mail : rudisiago@umgo.ac.id
}

\begin{abstract}
Abstrak
Nelayan Gorontalo telah mengkombinasikan beberapa bahan umpan buatan dengan macam-macam warna pada alat tangkap pancing ulur. Warna dominan pada umpan yang digunakan tersebut yaitu wana merah dan warna kuning. Untuk mendapatkan informasi ilmiah terhadap perbandingan hasil tangkapan pada umpan warna merah dan warna kuning maka dilakukan suatu penelitian. Penelitian ini bertujuan mengetahui perbedaan rata-rata jumlah hasil tangkapan pada pancing yang menggunakan umpan pentil warna merah dan warna kuning. Jumlah sampel sebanyak 62 sampel dimana 31 sampel hasil tangkapan umpan warna merah dan 31 sampel hasil tangkapan umpan warna kuning. Data dianalisis dengan menggunakan Uji T Sampel Independen dengan menggunakan SPSS 20. Berdasarkan hasil perhitungan nilai rata-rata hasil tangkapan, pancing yang menggunakan umpan pentil warna merah memperoleh 18 ekor ikan kembung dibandingkan pancing yang menggunakan umpan pentil warna kuning sebanyak 16 ekor ikan kembung. Berdasarkan perhitungan statistik menggunakan Uji T Sampel Independen diperoleh nilai T hitung 1,38 < 2,00 (T Tabel) yang berarti bahwa penggunaan umpan warna merah dan warna kuning tidak memiliki perbedaan yang signifikan terhadap jumlah hasil tangkapan ikan kembung.
\end{abstract}

Kata Kunci : Pancing Ulur, Warna Umpan, Ikan Kembung, Teluk Tomini

\begin{abstract}
Gorontalo's fishermen have combined several artificial bait materials with various colours on a stretch fishing gear. The dominant colour in the bait used is red and yellow. a study was conducted to get scientific information on the comparison of catches using the red and yellow bait. This study aims to determine the difference in the average number of catches on fishing rods using red and yellow bait. The number of samples was 62 samples where 31 samples were captured by red bait and 31 samples were obtained by yellow bait. Data were analyzed using Independent Sample T Test using SPSS 20. Based on the calculation of the average catch value, fishing rods using red nipple bait obtained 18 mackerel fish compared to fishing rods which used yellow nipples as many as 16 mackerel fish. Based on statistical calculations using the Independent Sample $T$ Test obtained $T$ count value $1.38<2.00$ (T Table) which means that the use of red and yellow bait does not have a significant difference in the amount of the mackerel catched.
\end{abstract}

Keywords: Threaded Fishing Line, Bait Color, Mackerel, Tomini Bay 


\section{Pendahuluan}

Modifikasi alat tangkap melalui penelitian uji coba pada pengoperasian alat tangkap pancing telah dilakukan oleh beberapa peneliti. Penelitian untuk umpan tiruan dengan warna yang berbeda seperti dalam penelitian Syafrie (2008), Penggunaan umpan tiruan berwarna perak ternyata menghasilkan tangkapan terbanyak dan Umpan berwarna merah menghasilkan tangkapan kedua terbanyak sementara umpan warna hijau menghasilkan tangkapan terbanyak ketiga terhadap ikan cakalang pada alat tangkap huhate di Perairan Bone-Bone Kota BauBau.

Pada penelitian Niam et.al (2013), juga mengenai perbedaan warna umpan tiruan terhadap hasil tangkapan ikan tongkol (Euthynnus affinis) pada alat tangkap pancing tonda di Perairan Karimunjawa Jepara Sulawesi Tenggara dimana diperoleh bahwa penggunaan umpan tiruan warna merah pada alat tangkap pancing tonda berpengaruh terhadap hasil tangkapan ikan Tongkol (Euthynnus affinis) dan mendapatkan hasil tangkapan terbanyak dibandingkan umpan warna umpan hijau dan biru serta warna putih sebagai kontrol. Dalam penelitian Puspito (2010), diperoleh bahwa umpan tiruan warna perak memberikan hasil tangkapan yang tinggi dimana rata-rata menghasilkan 0,67 ekor/menit, kemudian diikuti oleh umpan warna merah dengan rata-rata hasil tangkapan 0,58 ekor/menit dan pada umpan warna hijau diperoleh hasil tangkapan 0,47 ekor/menit. Hasil penelitian Paransa et.al (2014) juga mengenai hasil Pengaruh warna umpan buatan terhadap hasil tangkapan pancing noru di Perairan Teluk Manado dimana diperoleh umpan buatan warna merah dan biru yang paling banyak memberikan hasil tangkapan ikan pelagis kecil yakni ikan selar (Selaroides sp) dan ikan malalugis (Decapterus sp) Sedangkan waktu operasi yang terbaik adalah pada jam 18.00 sampai dengan 20.59. Imbir et al (2015), melakukan penelitian umpan berwarna dimana hasil tangkapan kain sutra berwarna merah lebih unggul dibandingkan dengan kain sutra berwarna merah muda pada ikan tongkol. Untuk penelitian pancing ulur sendiri juga sudah ada kajian seperti dalam penelitian Kurnia et.al (2015), pengaruh perbedaan ukuran mata pancing terhadap hasil tangkapan pancing ulur di Perairan Pulau Sabutung Pangkep dimana hasil tangkapan ikan yang paling banyak tertangkap selama penelitian yaitu sebesar $41,2 \%$ yaitu 364 ekor dari keseluruhan hasil tangkapan.

Penelitian yang berkaitan dengan alat tangkap pancing ulur, jenis umpan yang digunakan dan jenis penelitian jenis ikan kembung di perairan Teluk Tomini masih sangat kurang sehingga perlu dilakukan penelitian terkait dengan respon ikan kembung terhadap umpan tiruan berbahan pentil dengan warna merah dan warna kuning.

\section{Metode penelitian}

\subsection{Waktu dan tempat penelitian}

Penelitian dilaksanakan selama tiga bulan yaitu pada Bulan November 2017 sampai dengan Bulan Januari 2018 yang meliputi tahap pengusulan, persiapan, survey lapangan, pengumpulan data primer, proses pengolahan data dan penyusunan laporan. Lokasi penelitian dilaksanakan di Perairan Teluk Tomini sementara fishing base berada di pesisir Kota Gorontalo Provinsi Gorontalo.

\subsection{Pengambilan data}

Jenis data meliputi data primer yaitu mengukur langsung dilapangan oleh enumerator dengan mengikuti proses kegiatan penangkapan ikan. Proses pengumpulan data primer dengan mencatat ikan hasil tangkapan pada umpan merah maupun umpan warna kuning. Jumlah pemancing pada trip pertama sampai dengan trip keempat sebanyak 6 orang dan pada trip kelima jumlah pemancing berjumlah 7 orang sehingga total sampel sebanyak 31. Dalam satu sampel atau satu orang pemancing, pancing yang digunakan terdiri dari 13 - 35 mata 
pancing yang berselang seling antara umpan pentil warna merah dan umpan pentil berwarna kuning. Dari ke 31 sampel tersebut diperoleh 62 data yaitu 31 data hasil tangkapan ikan kembung pada umpan pentil warna merah dan 31 data hasil tangkapan ikan kebung pada umpan warna kuning.

Variabel dalam penelitian ini yaitu warna umpan (umpan pentil warna merah dan umpan pentil warna kuning) sebagai variabel bebas sedangkan jumlah hasil tangkapan merupakan variabel terikat. Dalam melakukan pengujian terhadap variabel-variabel tersebut terlebih dahulu mentukan hipotesis yang digunakan. Hipotesis dalam penelitian ini dijelaskan sebagai berikut :

(1) Hipotesis $\mathrm{Nol}\left(\mathrm{H}_{0}\right)$

Tidak ada perbedaan yang signifikan pada hasil tangkapan pancing ulur yang menggunakan umpan pentil warna merah dengan umpan warna kuning, $\mathrm{H}_{0}: \mu 1=\mu 2$ (tidak berbeda).

(2) Hipotesis Alternatif $\left(\mathrm{H}_{1}\right)$

Ada perbedaan yang signifikan pada hasil tangkapan ikan kembung pada pancing ulur yang menggunakan umpan pentil merah dengan umpan pentil kuning, $H_{1}: \mu 1 \neq \mu 2$ (berbeda).

Sebelum uji hipotesis, maka terlebih dahulu dilakukan uji persyaratan analisis. Adapun persyaratan dalam analisis ini yaitu normalitas dilakukan pada traf signifikansi 0,05. Kaidah keputusannya yaitu : jika $X^{2}{ }_{\text {hitung }} \geq X^{2}{ }_{\text {tabel }}$ maka distribusi tidak normal dan jika $X^{2}{ }_{\text {hitung }} \leq X^{2}$ tabel maka data tersebut berdistribusi normal (Riduwan, 2008:119). Pengujian normalitas data dapat pula dilakukan dengan membandingkan nilai signifikansi denan nilai alfa. Jika nilai sig $<$ alfa $(\alpha)$ maka data tidak normal dan Jika nilai sig $>$ alfa $(\alpha)$, berarti data berdistribusi normal. Secara keseluruhan proses pengolahan data tersebut menggunakan aplikasi komputer Microsoft Excel 2007 dan IBM SPSS Statistic Version 21.

\section{Hasil dan Pembahasan}

\subsection{Konstruksi pancing dan jenis umpan}

Bentuk dan konstruksi yang digunakan oleh nelayan dimana dalam satu gulungan pancing terdapat 13 sampai 25 jumlah pancing. Jenis tali/senar yang digunakan adalah jenis PE monofilamen dengan nomor benang pada tali utama pada pancing ulur yaitu nomor 12 sedangkan nomor tali cabang pada alat tangkap pancing ulur yaitu nomor enam. Pancang tali cabang pada alat tangkap tersebut yaitu $5 \mathrm{~cm}$ sedangkan jarak antara pancing berjarak satu meter.Pemberat yang digunakan dari bahan besi bekas atau potongan besi. Dalam konstruksi pancing tersebut dipasang kili-kili dengan fungsi agar tali utama dan tali pancing tidak mudah terpintal atau kusut pada saat penarikan pancing ke atas perahu.Konstruksi alat tangkap yang digunakan oleh nelayan (Gambar 1).

Jenis umpan yang digunakan berbahan benang sutra atau benang kain yang berwarnawarni yang sebutan lokalnya dengan namapasir intan. Selain dari bahan tersebut, masyarakat nelayan juga menggunakan umpan tiruan yang berbahan karet pentil dengan warna merah dan warna kuning.Dalam setiap gulungan pancing terdapat banyak variasi warna dan bahan yang dipadukan pada satu kail pancing namun ada pula bahan dan warna yang tunggal pada satu kail pancing seperti bahan pentil warna merah dan bahan pentil berwarna kuning.Bahan umpan buatan pada pancing pancing ulur (Gambar 1). 


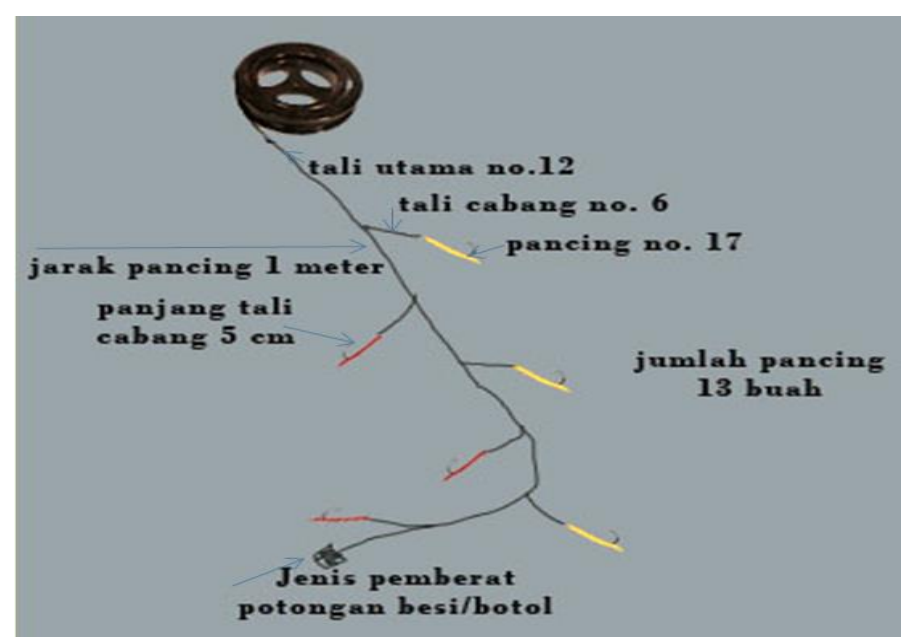

Gambar 1. Konstruksi alat tangkap pancing ulur

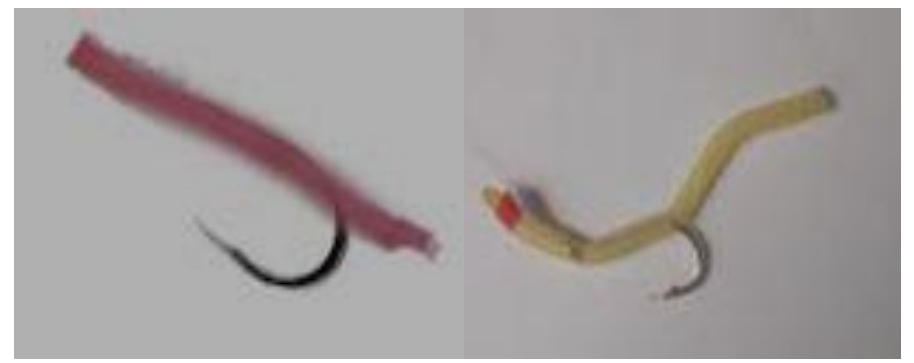

Gambar 2. Jenis dan warna umpan pada pancing ulur

Penggunaan nomor pancing oleh nelayan disesuaikan dengan ikan target yaitu untuk ikan layang dan ikan kembung digunakan pancing no 7 sesuai dengan pengalaman nelayan dalam melakukan pemancingan. Penggunaan nomor pancing oleh nelayan juga berdasarkan bukaan mulut ikan target dimana menggunakan pancing nomor 7 , hal ini untuk memberikan peluang untuk ikan-ikan kembung yang sedikit kecil dapat tertangkap.Sesuai dengan pendapat Al's et al. (2008) bahwa ukuran mata pancing signifikan mempengaruhi komposisi jenis hasil tangkapan ikan.Mata pancing yang dugunakan merupakan mata pancing yang umum dipakai oleh nelayan yaitu nomor 7 dalam penangkapan ikan kembung. Dalam penelitian Adityarini atal (2012), penggunaan mata pancing biasa pada alat tangkap pancing ulur relatif memperoleh hasil tangkapan yang lebih tingi dibandingkan dengan mata pancing kirbed bersudut $30^{\circ}$.

\subsection{Perbedaan rata-rata hasil tangkapan dengan warna upan yang berbeda}

Rata-rata hasil tangkapan pancing ulur pada umpan tiruan dengan bahan pentil warna merah dan bahan pentil berwarna kuning (Tabel 1 dan Gambar 3).

Tabel 1. Rata-rata hasil tangkapan ikan kembung pada alat tangkap pancing ulur

\begin{tabular}{llllll}
\hline Jenis Umpan & N & Minimum & Maximum & $\begin{array}{l}\text { Rata-rata } \\
\text { tangkapan }\end{array}$ & hasil \\
\hline umpan pentil warna merah & 31 & 8 & 32 & 18 \\
umpan pentil warna kuning & 31 & 6 & 27 & 16 \\
Valid N (listwise) & 31 & & & \\
\hline
\end{tabular}

Sumber : Data primer yang telah diolah 2017 


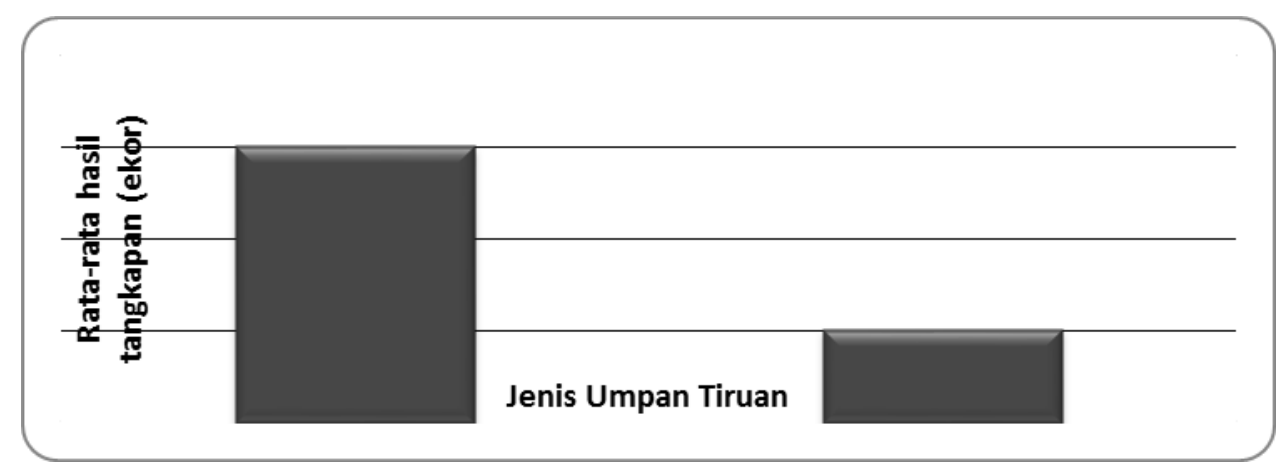

Gambar 3. Perbandingan rata-rata hasil tangkapan

Hasil analisis statistik deskriptif pada tabel di atas terlihat bahwa terdapat perbedaan nilai rata-rata hasil tangkapan dari kedua alat tangkap tersebut. Ratarata hasil tangkapan tertinggi terdapat pada alat tangkap pancing ulur yang menggunakan umpan warna merah dibandingkan dengan alat tangkap pancing yang memiliki umpan warna kuning.

\subsection{Analisis hasil tangkapan}

a) Uji Normalitas Data

Berdasarkan hasil analisis uji kenormalan data diperoleh bahwa data hasil tangkapan yang dianalisis telah berdistribusi normal, dapat dilihat pada tabel 2 .

Tabel 2. Hasil Uji kenormalan data (Shapiro-Wilk)

\begin{tabular}{lc}
\hline Data hasil tangkapan & Sig. \\
\hline Umpan pentil warna merah & 0.838 \\
\hline Umpan pentil warna kuning & 0.345 \\
\hline
\end{tabular}

Sumber : Data primer yang telah diolah 2017

Pada tabel di atas nilai signifikansi pada umpan tiruan berbahan pentil warna merah diperoleh nilai $(\mathrm{Sig}) 0.838>0.05(\alpha)$ yang berarti penyebaran data telah berdistribusi normal, demikian halnya nilai signifikansi pada umpan tiruan berbahan pentil berwarna kuning diperoleh (Sig) $0.345>0.05(\alpha)$ yang berarti penyebaran datanya telah berdistribusi normal. Hasil uji kenormalan data merupakan syarat dan asumsi yang harus dipenuhi dalam penggunaan analisis uji $\mathrm{T}$ dan dalam hal ini pengujian analisis uji $\mathrm{T}$ dapat dilakukan.

\section{b) Uji T Sampel Independen}

Berdasarkan hasil analisis Uji T diperoleh nilai signifikansi (Sig) $0.172>$ $0.05(\alpha)$ atau nilai $\mathrm{T}$ hitung $1.38<2.00(\mathrm{~T}$ Tabel) maka hipotesis nol $(\mathrm{H} 0)$ diterima dan (H1) ditolak, yang berati bahwa hasil tangkapan pada pancing yang menggunakan umpan tiruan berwarna merah tidak berbeda signifikan dengan hasil tangkapan pada pancing yang menggunakan umpan berwarna kuning. Hasil analisis uji -t dapat dilihat pada tabel 3.

Tabel 3. Hasil analisis Uji T

\begin{tabular}{lllcc}
\hline & \multicolumn{3}{c}{ Indepentent sampel T test } \\
\hline & T hitung & T.Tabel & Nilai Sig. & Nilai $(\alpha)$ \\
\hline Hasil tangkapan (ekor) & 1.38 & 2.000 & 0.172 & 0.05
\end{tabular}


Dari hasil analisis uji $\mathrm{T}$ tersebut dapat pula dinterpretasikan bahwa hasil tangkapan pada pancing yang menggunakan umpan warna merah relatif sama dengan hasil tangkapan pada pancing yang menggunakan umpan warna kuning. Penggunaan bahan pentil sebagai warna umpan merah dan kuning dalam pemancingan ikan kembung memiliki hasil tangkapan yang relatif sama atau tidak memiliki perbedaan hasil tangkapan yang signifikan, diduga karena pada ikan kembung memiliki kepekaan yang sama terhadap warna merah dan warna kuning. Hal ini sejalan dengan penelitian (Najamuddin, et.al 1994 dalam Fujaya, 2004) yang mengatakan bahwa ikan pelagis seperti ikan layang, tembang dan ikan kembung sangat peka terhadap warna merah dan warna kuning.

Kegiatan pemancingan dalam penelitian ini dilakukan pada malam hari sehingga dimungkinkan ikan memiliki respon yang sama terhadap kedua umpan warna merah maupun warna kuning. Menurut Fujaya (2004), Sensitivitas dan ketajaman mata tergantung pada terangnya bayangan yang mencapai retina. Berbeda pada respon ikan tongkol dengan ikan kembung sebagaimana dengan hasil penelitian Niam et.al (2013), bahwa umpan tiruan warna merah merupakan umpan tiruan yang paling efekktif dibandingkan dengan ketiga warna umpan tiruan lainnya (putih, hijau dan biru) pada alat tangkap huhate (poleandline juga dalam penelitian Syafrie (2008) dan puspito (2010) dimana umpan warna merah merupakan umpan terbaik kedua setelah umpan warna perak pada alat tangkap huhate, karena penangkapannya dilakukan pada siang hari dimana warna merah lebih mencolok dan lebih mengkilap atau memantulkan cahaya. Demikian halnya dalam penelitian Susanto et al (2012) dikatakan bahwa umpan tipuan warna merah paling banyak mendapatkan hasil tangkapan ikan cakalang dari pada umpan tiruan warna hijau.

Penangkapan ikan kembung pada malam hari dengan menggunakan umpan tiruan berbahan pentil yang warna merah memiliki hasil tangkapan yang relatif sama dengan umpan tiruan berbahan pentil berwarna kuning. Hal ini dimungkinkan juga bahwa umpan tiruan tersebut direspon sama baiknya, baik warna umpan merah maupun umpan berwarna kuning, berhubung karena kurangnya cahaya yang mengenai umpan tiruan tersebut akibat cahaya lampu yang ada di atas kapal hanya sebagian cahaya yang masuk kedalam perairan dan sebagian pula terpantulkan. Hal tersebut sejalan dengan pendapat (Sidjabat, 1973 dalam Rosyidah et al, 2011) yaitu Apabila cahaya menyinari ke permukaan air, maka sebagian cahaya akan dipantulkan dan sebagian pula akan diteruskan ke dalam air. Dikatakan pula Fujaya (2004), Sensitivitas dan ketajaman mata tergantung pada terangnya bayangan yang mencapai retina mata ikan dan menurut Hajar (2008), Sensifitas mata ikan dalam merespon visual dapat diidentifikasi berdasarkan kontraksi dari sel kon dengan melihat pergerakan dari elipsoid kon di dalam lapisan sel penglihatan (Visual cell Layer).

\section{Kesimpulan dan Saran}

Hasil penelitian pada alat tangkap pancing ulur yang menggunakan umpan pentil warna merah dengan pentil warna kuning menunjukkan bahwa hasil uji hipotesis independent sample $t$ test dimana $t_{\text {hitung }}$ sebesar 1,38 dan $\mathrm{t}_{\text {tabel }} 2,00\left(\mathrm{t}_{\text {hitung }}\right.$ $>\mathrm{t}_{\text {tabel }}$ ), maka $\mathrm{H}_{0}$ diterima dan $\mathrm{H}_{1}$ ditolak. Jadi dapat disimpulkan bahwa hasil tangkapan ikan kembung pada pancing ulur dengan umpan berbahan pentil warna merah, tidak memiliki perbedaan yang signifikan dengan hasil tangkapan pada 
pancing ulur yang berbahan pentil warna kuning dalam kegiatan pemancingan malam hari.

Perlu dilakukan penelitian lanjutan terhadap kombinasi-kombinasi warna umpan terhadap respon ikan kembung dalam kegiatan pemancingan malam hari serta perlu dilakukan penelitian terhadap respon ikan kembung terhadap umpan berbahan pentil warna merah dan warna kuning pada kegiatan pemancingan siang hari.

\section{Daftar Pustaka}

Adityarini, S., Asriyanto\&Wibowo, P. (2012). Pengaruh Penggunaan Perbedaan Konstruksi Mata Pancing Dan Jenis Umpan pada Pancing Ulur terhadap Hasil Tangkapan di Kawasan Zona Pemanfaatan Perikanan Tradisional Taman Nasional Karimunjawa. Journal of Fisheries Resources Utilization Management and Technology, 1(1), 97-107.

Alós, J., Palmer, M., Grau, A. M., \& Deudero, S. (2008). Effects of hook size and barbless hooks on hooking injury, catch per unit effort, and fish size in a mixed-species recreational fishery in the western Mediterranean Sea. ICES Journal of Marine Science, 65(6), 899-905.

Fujaya, Y. 2004. Fisiologi Ikan. PT. Rinneka Cipta. Jakarta. hal.28-29

Hajar, M.A.I. (2008). Visual Acuity of Pasifis Saury Cololabis saira for Understanding Capture Process. Tokyo University of Marine Science and Technology. Tokyo. Marine Fisheries Research Journal. Vol. 69: 789-791.

Hidayat, T., Noegroho, T., \& Wagiyo, K. (2017).Truktur Ukuran Dan Beberapa Parameter Populasi Ikan Cakalang (Katsuwonus pelamis Linnaeus, 1758) Di Samudera Pasifik Utara Papua. BAWAL Widya Riset Perikanan Tangkap, 9(2), 113-121.

Imbir, F. F., Patty, W., \& Wenno, J. (2015).Pengaruh warna umpan pada hasil tangkapan pancing tonda di perairan Teluk Manado Sulawesi Utara. Jurnal Ilmu dan Teknologi Perikanan Tangkap, 2(1) : 9-13.

Kurnia, M., \& Yusuf, M. (2015).Pengaruh Perbedaan Ukuran Mata Pancing Terhadap Hasil Tangkapan Pancing Ulur Di Perairan Pulau Sabutung Pangkep (Effects of Difference of Hook Size on the Catch of Handline in Sabutung Island Waters of Pangkep Regency). Marine Fisheries: Journal of Marine Fisheries Technology and Management, 6(1), 87-95.

Niam, A., Fitri, A. D. P., \& Yulianto, T. (2013).Perbedaan Warna Umpan Tiruan Terhadap Hasil Tangkapan Ikan Tongkol (Euthynnus Affinis) Pada Alat Tangkap Pancing Tonda Di Perairan Karimunjawa Jepara. Journal of Fisheries Resources Utilization Management and Technology, 2(3), 202212.

Paransa, I. J., Tipinbu, W. R., \& Kumajas, H. J. (2014).Pengaruh warna umpan buatan terhadap hasil tangkapan pancing noru di perairan Teluk Manado. Jurnal Ilmu Dan Teknologi Perikanan Tangkap, 1,78-84.

Puspito, G.(2010).Warna Umpan Tiruan Pada Huhate. Jurnal Saintek Perikanan, $16(1), 1-7$.

Riduwan. (2010). Dasar-Dasar Statistika. Bandung : Alfabeta . Riwidikdo H. 2007. Statistik Kesehatan. Yogyakarta : Mitra Cendikia Press 
Rosyidah, I, N., Farid, A., \&Nugraha, W, A. (2011). Efektivitas Alat Tangkap Mini Purse Seine Menggunakan Sumber Cahaya Berbeda Terhadap Hasil Tangkap Ikan Kembung (Rastrelliger sp.).Jurnal Ilmiah Perikanan dan Kelautan, 3(1).

Syafrie, H.(2008).Ujicoba beberapa warna umpan tiruan pada penangkapan ikan dengan huhate di perairan bone-bone, kota bau-bau, sulawesi tenggara. Skripsi. Institut Pertanian Bogor.

Susanto, E., Boesono, H., \& Fitri, A. (2012).Pengaruh Perbedaan Penggunaan Umpan Terhadap Hasil Tangkapan Ikan Cakalang (Kastsuwonus pelamis) pada Alat Tangkap Huhate di Perairan Ternate Maluku Utara. Journal of Fisheries Resources Utilization Management and Technology, 1(1), 138147.

Zamroni, A., Suwarso, S., \& Kuswoyo, A. (2017).Variasi Genetika Ikan Banyar, Rastrelliger kanagurta (Cuvier, 1817) Di Perairan Indonesia Timur. BAWAL Widya Riset Perikanan Tangkap, 9(2), 123-131. 